\title{
Brown coals of Far East - natural resource for multipurpose industrial processing
}

\author{
Anatoliy Sorokin ${ }^{* 1,2}$ and Andrey Konyushok ${ }^{1,2}$ \\ ${ }^{1}$ Amur Scientific Center FEB RAS, Blagoveshchensk, Russia. \\ ${ }^{2}$ Institute of Geology and Nature Management FEB RAS, Blagoveshchensk, Russia.
}

\begin{abstract}
Annotation. The analysis of the potential economic value of brown coals of the Far East of Russia is carried out when to use them as a complex chemical mineral resource. It was conducted assessment of industrial attractiveness to use coal combustion or coal chemical processing wastes as an additional source of gold, rare metals and rare earth elements. The Sergeevskoye brown coal deposit of the Zeya-Bureya Sedimentary Basin in the Amur Region was proposed as a potential standard facility for the construction of a coal-chemical processing plant to produce resin, montan wax, complex hydrocarbons with associated gold, rare metals and rare earth elements recovery.
\end{abstract}

\section{Introduction}

In the economic complex of Russia and a number of other countries, according to experts' forecasts, hard, bituminous and brown coals remain the main sources of thermal and electric power at Thermal Power Plants. In the Amur region, the total predicted resources of brown and hard coal reach almost 70 billion tonnes, of which 43 billion tonnes are concentrated in the Zeya-Bureya sedimentary basin [1]. Balance reserves in the basin in the amount of 3.8 billion tonnes were explored in 7 deposits (Svobodnoye, Sergeevskoye, Tygdinskoye, Yerkovetskoye, Raichikhinskoye, Arkharo-Boguchanskoye, Ogodzhinskoye). They are represented mainly by lignite and brown coal $-99.1 \%$, the rest bituminous coal. All deposits are suitable for open pit development. At present, Raichikhinskoye and Yerkovetskoye brown coal deposits of technological group 2B are being excavated, which have reserves of 1.3 billion tonnes. But the main ones are coals of group 1B (2.3 billion tonnes), which are low-quality raw materials that are not suitable without enrichment as energy fuel, but are very promising as a complex chemical and rare metal resource.

At the same time, coal demand as an energy resource will remain relatively stable until 2033, despite the increase in the use of natural gas for power generation. This is due to the forecast of the outstripping demand for electricity, justified by economic factors, including population growth on the planet [2]. Accordingly, along with the development of technologies that increase the efficiency of using brown coal as a fuel, in Russia and elsewhere in the world, research is underway to improve the technologies for coal

\footnotetext{
* Corresponding author: amurnc@ascnet.ru
} 
combustion, chemical processing, extraction of mineral components and metals from coal combustion products $(\mathrm{CCP})$.

\section{Experimental and analytical research results}

Due to chemical processing (coal chemistry), brown coal is converted into liquid fuel and combustible gases. In addition, modern technologies make it possible to produce from brown coals more than 130 types of chemical products and semi-finished products, which are further used for the production of more than 5,000 types of products [3], and extract rare metals and rare earth elements from the CCP. One of the most popular chemical products is montan wax, which is extracted from semi-bituminous varieties of brown coal. This is one of the most durable of natural waxes, which finds application in many industries. It is used mainly in the production of plastics, especially in compounds based on engineering plastics such as polyvinyl chloride, polyamide, polycarbonate, thermoplastic polyurethane and styrene-maleic anhydride. Experimental extraction processing of coals of Svobodnoye, Sergeevskoye and Tygdinskoye deposits allowed to obtain from them at least $12 \%$ of raw wax in terms of dry coal [4]. In these pilot experiments the technology of liquid phase catalytic alkylation of coal by aliphatic alcohols, developed by the scientists of AmurNC and IGNM FEB RAS, was used. The application of this method contributes not only to a significant deepening of the extraction process and to the growth of extraction of bitumen and waxes, but also to the production of a modified raw wax enriched with highmolecular ester fractions [5].

At the same time, it became possible to exclude from the production process a laborious, but insufficiently effective, step of demineralizing wax. The basic physicochemical characteristics of the modified wax are comparable with those of esterified waxes, for which multistage technologies are used that significantly increase the cost of the final product. As a result, a method has been developed in which the modified coal is enriched with high molecular weight components, and the wax extracted from it, with a resin content near $2.5 \mathrm{wt}$. \%, does not require multistage processing technology.

In addition to wax, other products extracted from brown coal during processing are also of economic value: resins, humates, carboxylic acids, ethers and a solid residue as a raw material for liquefaction processes, production of inexpensive adsorbents, ion-exchange materials and others.

At pilot plants in Primorye, thermal processing of brown coal at the Lipovetskoye deposit was already performed at low temperature parameters $(820-920 \mathrm{~K})$. The yield of resin was $8.8 \%$ for dry fuel. When a coal had a semi-coked rank, 17 to $30 \mathrm{wt}$. \% of the resin was obtained, based on the combustible mass. Experimental and industrial research was also conducted at the Artyomovskoye coal field in Primorye, where semi-coke $(56.2 \%)$, resin $(4.83 \%)$, dry gas $(7 \%)$, gasoline $(0.17 \%)$ and organic substances $(0.3 \%)$ were obtained by thermal decomposition [6].

High porosity characteristics of brown coal make it suitable for the production of carbon-containing materials that can be used as inexpensive adsorbents for purification of drinking water from soluble volatile compounds and organic compounds of low molecular weight. The increased content of functional groups (carboxyl, phenolic hydroxyls) in brown coals stimulates the development of studies in the field of the use of coal as a cheap ionexchange medium for the recovery of valuable metals or the recovery of heavy metals from aqueous solutions [3].

It should be noted that wide application of brown coal for agricultural and horticultural purposes is possible. Humic acids derived from coals are used as a soil conditioner and as a fertilizer. Brown coal absorbs ammonium on its surface, which turns it into a nitrogen fertilizer. The technology for producing oxidized humates was developed by the scientists 
of the AmurNC and the Institute of Geology and Nature Management of the Far East Branch of RAS for coals of the Svobodnoye, Sergeevskoye, Sianchik, and Yerkovetskoye deposits [7]. It is established that humates are most effectively extracted with $0.5-1.0 \mathrm{wt} . \%$ solution of $\mathrm{NAOH}$. The yield of humates from coal 1B was obtained in the range of 55- 65 wt. \% per organic mass. The best yields were given by low-ash coals. The product was tested in 2006-2007 on soybean fields, wheat, barley sowings in the experimental farming fields of the Institute of Soy of FEB RAS. The dose of $10 \mathrm{~g}$ of dry humates per $100 \mathrm{sq} . \mathrm{m}$ gives a statistically significant increase in the yield of grain crops of 1.2, 2.0 and $3.8 \mathrm{~kg} /$ 100 sq. $\mathrm{m}$, respectively.

Noble metal (NM) mineralization is found in a number of coal-bearing basins of Siberia, Transbaikalia, the Far East, Great Britain, USA, Uzbekistan, China and other countries [8]. In addition to NM, coal is enriched by rare metals and rare earth elements (REE), which are usually associated with $\mathrm{Au}$ and $\mathrm{Pt}$ in the coal deposits of Siberia (Nazarovo, Borodino), Priamurye (Raichikhinskoye, Yerkovetskoye, Darmakanskoye, etc.), Primorye (Pavlovskoye, Bikinskoye, Khasanskoye, Shkotovskoye) $[1,8,9,10]$. In recent years, Russia Geological Institute (St. Petersburg) has been working with the aim of making an economic assessment of the metalliferous of coal in coal-bearing deposits. According to their data, the main coal deposits of the Far East contain significant resources of Sc, Ga, $\mathrm{Ge}, \mathrm{Rb}, \mathrm{Sr}, \mathrm{Cs}, \mathrm{Zr}, \mathrm{Y}, \mathrm{REE}$ and platinum. At the same time, for most of the metalliferous coal deposits there is no reliable technology for estimating the content of valuable impurity elements, the conditions and mechanisms of concentration, the form of disseminating have not been studied, the technology of their extraction has not been developed, and the prevalence of useful components along the deposit of the coal seam. But with the improvement of technologies for extracting RM and REE from CCP, a significant increase in the profitability of coal processing at coal-chemical enterprises is possible [12].

In brown coals deposits investigated by the authors, besides of decaying organic matter, there is a significant proportion of clay and accessory minerals transported to coal-bearing strata from surrounding mountain massifs during the formation of primary peatlands. According to our data, the abundance of chemical elements in coal and their relationship to a particular mineral form varies depending on the history of the formation of the coal basin as a whole, such as coal-bearing area, even within a single coal seam. The prevalence of gold ore and rare metal deposits, phosphate deposits with rare earth elements in the rocks around the coal basin led to the accumulation a wide range of chemical elements in the coals. They are connected both with the organic matter of coals, and with the composition of minerals (monazite, zircon, cassiterite, apatite, clay minerals and others). At the same time, the total metal content of the Miocene coals (the Sergeevskoye deposit) turned out to be much larger than the Paleocene deposits (Raichikhinskoye and Yerkovetskoye deposits).

Ash content of brown coals in the Zeya-Bureya basin ranges from 13 to 24 wt. \%. After coal combustion, the concentrations of some chemical elements in the ash, for example, $\mathrm{Si}$, $\mathrm{Al}, \mathrm{S}, \mathrm{Fe}$ and $\mathrm{Ca}$, can be in the amount of up to $15-30 \mathrm{wt}$. \%. The concentration of metals in slag, ash and adsorbed gas-dust mixture increases several times - for example, for $\mathrm{Zn} 30$ times, Rb - 14 times, Y - 4 times. Among the most valuable RM studied by the authors in brown coals of the Zeya-Burea basin are $\mathrm{Li}, \mathrm{Be}, \mathrm{Zr}$, $\mathrm{Ta}, \mathrm{Nb}$, and from the group of rareearth elements - Y and Sc. According to [13], for many coal deposits, abnormally high REE contents, with the exception of $\mathrm{Ce}$ and $\mathrm{Eu}$, and also in some cases $\mathrm{La}, \mathrm{Gd}$ and $\mathrm{Y}$, are not typical. However, we have determined the high REE $+\mathrm{Y}$ content in the coals of the

Sergeevskoye deposit (Miocene) (up to $200 \mathrm{~g} / \mathrm{t}$ ) against $60-100 \mathrm{~g} / \mathrm{t}$ in the coals of the Yerkovetskoye deposit (Paleocene). The content of Be, Ta, Ni, Hf, Sn, W, Ti in the coals of the Zeya-Bureya Basin is insignificant. Analysis of data on the distribution of useful components along the Northwestern frame of the basin indicates that Miocene coals in the lower horizons of the coal bed are characterized by industrial concentrations of $\mathrm{Li}, \mathrm{Sc}, \mathrm{Ga}$ 
and $\mathrm{Cs}$. The exceptions are $\mathrm{Y}$ and $\mathrm{Zr}$ - their content in the upper part of the coal cuts is higher, as well as the Au content. In the Paleocene deposits of the Raichikhinskoye and Yerkovetskoye deposits, the Au and RM are unevenly distributed. Au is enriched in the middle and lower horizons of the coal seam, mainly in the Yuzhnoye quarry (up to $3.3 \mathrm{~g} / \mathrm{t}$ ). Elevated concentrations of $\mathrm{Li}, \mathrm{Cs}$ and $\mathrm{Ga}$ are also observed in the lower parts of the coal seam, and $\mathrm{Y}$ and $\mathrm{Zr}$ are predominant in the upper.

The brown coals of the Zeya-Bureya Basin have geodynamic and geochemical affinities with rocky framing complexes and contain $\mathrm{Cr}, \mathrm{Cs}, \mathrm{Cu}, \mathrm{Ga}, \mathrm{Li}, \mathrm{Ni}, \mathrm{Rb}, \mathrm{Sn}, \mathrm{Sr}, \mathrm{Ta}, \mathrm{Th}, \mathrm{Ti}, \mathrm{U}$, $\mathrm{V}, \mathrm{Y}$ and REE. Our research indicates that these elements, as a rule, are found in clay minerals (in kaolinite, montmorillonite and feldspar) and in tuff tonsteins in coal.

Industrial values of $\mathrm{Cs}, \mathrm{Ga}, \mathrm{Li}, \mathrm{Ti}$, and $\mathrm{V}$ are found in coal seams in clay minerals kaolinite, illite, smectite, and also in chlorite and carbonates. REE and also Y and Sc, are found mainly in phosphates and organic matter of coals [15].

An attempt to determine the profitability of extraction of elements from coal deposits containing $\mathrm{Au}$ and $\mathrm{Ga}$ in particular is undertaken in China. Approximately, these concentrations were established for Au at a level of $0.2 \mathrm{~g} / \mathrm{t}$ and $60 \mathrm{~g} / \mathrm{t}$ for $\mathrm{Ga}$ [14]. The average content of $\mathrm{Au}$ in fresh coals of different ages is an average of $1.3 \mathrm{~g} / \mathrm{t}$. [1].

\section{Conclusions}

In the Far East region, the issues related to the restructuring and diversification of coalmining enterprises, the solution of socio-economic problems in some of its districts, the creation of new highly efficient and profitable industrial enterprises and industries are acute. The transition to innovations in the industry should be based on the use of scienceintensive technologies for the extraction and complex processing of coal minerals. The explored reserves of bituminous, brown and lignite coals allow to ensure the stable functioning of the enterprises of the fuel and energy complex and newly created enterprises for complex chemical processing of coal for many decades. This is recognized by many scientific, production and research organizations.

At present, the AmurNC and IGNM of FEB RAS continue an economic assessment of noble metal and rare metal mineralization in coal-bearing deposits in the Far East. According to our data, they contain significant resources of $\mathrm{Sc}, \mathrm{Ga}, \mathrm{Ge}, \mathrm{Rb}, \mathrm{Sr}, \mathrm{Cs}, \mathrm{Zr}, \mathrm{REE}$ $+\mathrm{Y}$ and noble metals. At the same time, the conditions and genesis of concentrating gold and metals, chemical and mineral forms of useful metals in coals require further study. With the improvement of technologies for extracting rare metals and REE from the CCP, a significant increase in the profitability of enterprises involved in the extraction, combustion and chemical processing of brown coal is possible.

The effective way of involving coals in complex processing in the Far East should be based on the study of their properties as chemical raw materials and the features of the accumulation and distribution of metals in coal processing products, both thermally and chemically. The prepared project for the development of the Sergeevskoye brown coal deposit (Amur region) can become a pilot object for the construction of a coal-chemical processing plant with the production of resin, montan wax, complex hydrocarbons, fertilizers with associated extraction of noble metals, rare metals and REE.

The work was financially supported by the Far East Program (project No. 18-02-019 "Geological and technological assessment of the resource potential of caustobioliths of the Far East, development of scientific basis for their integrated use with the production of competitive multi-purpose products"). 


\section{References}

1. Young Platforms of the Eastern Edge of Eurasia (Deep Structure, Conditions of Formation and Metallogeny), Ed. corr. member of RAS A.P. Sorokin, Vladivostok: The Dal'nauka, (2013).

2. Lucinda Tolhurst, Lucid Insight Ltd. http://cornerstonemag.net/commercial-recoveryof-metals-from-coal-fly-ash, (2015).

3. J.G. Speight, The chemistry and technology of coal. 3rd ed. Boca Raton: CRC Press. (2013).

4. L.P. Noskova, Solid Fuel Chem., 48, 4 (2014).

5. L.P. Noskova, A.V. Rokhin, A.P. Sorokin, Solid Fuel Chem., 41, 3 (2007).

6. Coal Resources of Russia. Coal Basins and Deposits of the Far East (Khabarovsk Territory, Amur Region, Primorsky Territory, Jewish Autonomous Region), M.: Geoinformmark», 5. Book 1. (1997).

7. A.P. Sorokin, I.F. Savchenko, V.Z. Mezhakov, T.V. Artyomenko, Phys. Techn. Probl. Dev. of Usefull. Resources, 4 (2012).

8. M.V. Golitsyn, V.I. Vyalov, A.Kh. Bogomolov, N.V. Pronina, E.Yu. Makarova, D.V. Mitronov, E.V. Kuzevanov, D.V. Makarov. Georesources. 61, 2 (2015).

9. V.I. Vyalov, A.I. Larichev, E.V. Kuzevanov, A.Kh. Bogomolov, M.I. Gamow. Region. Geol. and Metallogeny, 51 (2010).

10. V.V. Seredin Geol. Rudn. Mestor., 49, 1 (2007).

11. A.P. Sorokin, V.I. Rozhdestvina, V.M. Kuzminykh, S.M. Zhmodik, G.N. Anokhin, V.N. Mitkin. Geol. and Geophysics, 54, 7 (2013).

12. A.P. Sorokin, A.A. Konyushok, O.A. Ageyev. In the collection: Issues of Geology and Integrated Development of Natural Resources of East Asia, Fourth All-Russia. Sci. Conf., Blagoveshchensk: IGNM, Far Eastern Branch of the Russian Academy of Sciences. 2 (2016).

13. S. Dai, I.T. Graham, C.R. Ward. Intern. J. of Coal Geol., 159 (2016).

14. W. Wengfeng, S. Shuxun, H. Weiduo, W. Ran, Z. Jiefang, D. Piaopiao, Q. Yong, X. Shaochun. Fuel, 147 (2015) $15 . \quad$ W.H. Orem, R.B. Finkelman, In: McKenzie F.T., Ed., Sediments, Diagenesis, and Sedimentary Rocks: Treatise on Geochemistry. 7 ElsevierPergamon, Oxford, P. 191-222. (2003). 